\title{
The Odd Couple Revisited: A Quantitative Analysis of Perceived CFO - CEO Relationships in SDA North American Division Conferences
}

\author{
Theodore Brown Sr., Ph.D. \\ Professor of Management and Leadership, Oakwood University \\ Department of Business and Information Systems \\ School of Business, Huntsville, Alabama \\ Jean Lai Hing, M. S. \\ Assistant Professor of Management, Oakwood University \\ Department of Business and Information Systems \\ School of Business, Huntsville, Alabama
}

\begin{abstract}
Historically, CFOs and CEOs functioned in their own office silos, however, changes in how CFOs and CEOs relate to and work together in their organizations occurred due to the impact of Sarbanes-Oxley Act. The purpose of this paper is to examine CFO-CEO relationship data collected from SDA Conferences in North America utilizing Descriptive Statistics, ANOVAs and Chi-Square Analysis.
\end{abstract}

KEYWORDS: Board Governance, CEO (Chief Executive Officer/President), CFO (Chief Financial Officer/Treasurer), Executive Board, General Conference (GC), leadership, North American Division (NAD), perceptions, CEO-CFO relationships, Sarbanes-Oxley Act, SOX, SARBOX, Seventh-day Adventists (SDA)

\section{INTRODUCTION}

According to Ode (2016), the CEO is the leader of the organization; whereas the CFO, in most organizational sectors, is considered as the second in command to the CEO (Whiteman, 2015). The operational efficiency (Lin and Orvis, 2016) and effectiveness (Glamuzina, 2015; Kerns, 2015; Taylor, Cornelius and Colvin, 2014) of the organization; in addition to the financial wellbeing (Moulton, 2016) and overall health of the organization is contingent upon how good the relationship is between the CEO and CFO (Grove, 2016).

Historically, Chief Financial Officers (CFOs) and Chief Executive Offices (CEOs) have functioned in their own office silos tending to co-exist in the organization out of functional necessity rather than partnering cooperatively. However, in an effort to minimize corporate fraud, protect company assets, and improve financial reporting and board governance the SarbanesOxley Act of 2002 was legislated (Franklin, 2016; Aquilio, 2016; Joseph, 2015). The impact of this act has broken the CEO and CFO office silos; regulated CEO/CFO and Board organizational accountability (Krishnan, Gopal, Raman, Yang and Yu, 2011), and has fostered a more strategic partnership between the CEO and CFO (Butcher, 2011; M2 Presswire, 2012/Sept.).

\section{CFO and CEO Relationship: Adventist Context}

The global growth of the Seventh-day Adventist Church as a financial organization (Adventist World - NAD 2013, p. 5) has impacted how CEOs (Presidents) and CFOs (Treasurers) within the organization relate to each other as conference leaders. While the NAD Working Policy (2015-2016) and SDA Accounting Manual (2011) highlights the CEO (President) and CFO (Treasurer) functional positions and expected relationships with each other; uncertainty may 
exist pertaining to the extent of their relationships in terms of operating efficiency, effectiveness and positivity in their respective conferences.

As with various business and organizational sectors, SDA local conferences are also significantly influenced by changes occurring in our global environments and societies. Positive CEO and CFO relationships must be encouraged and nurtured. However, it is not clear whether the expectations (Buckingham and Coffman, 1999) and perceptions pertaining to the relationships of CEOs and CFOs in SDA local conferences are clearly articulated and understood by conference leadership which may negatively impact the relationship between the CEO and CFO.

\section{Organizational Effectiveness and Efficiency}

\section{LITERATURE}

Organizational policies, procedures, values and interpersonal treatment enhance managerial effectiveness of managers leading to positivity and productivity in organizations (Malbasic, Marimon and Mas-Machuca, 2016; Srivalli and Kota, 2016; Rangriz and Soltanieh, 2015; Yildiz, 2014). Organizational effectiveness and efficiency primarily depends upon an executive's leadership style inclusive of transformational and visionary leadership (Taylor, Cornelius and Colvin, 2014; Walter, 2014). Organizational effectiveness and efficiency examines and measures the relationship between management evaluations, employees performance and working towards the objectives, goals and mission of the organization (Horne, 2016; Lin and Orvis, 2016; Salhieh and Abu-Doleh, 2015)

Organizations influence employee behavior in an effort to assist them in understanding their responsibility in contributing to and improving the overall effectiveness and efficiency of their organization. In other words, their task significance and how it impacts the organization (Glamuzina, 2015).

\section{CEO/CFO and Organizational Effectiveness and Efficiency}

A crucial responsibility of the CEO, as the leader of the organization (Ode, 2016) and CFO is to foster and facilitate a good and healthy working relationship with each other (Baker, 2016; Grove, 2016; Caruso, 2015). They must serve and work together as partners providing support, leadership and encouragement not only to one another and the leadership team, but also to all employees to ensure that the organization is fulfilling its mission and achieving its performance and productivity goals (Schiff, 2016). There should be authentic and open communication (Vercic and Zerfass, 2016) between the CEO's and CFO's office. Within an organization they cannot operate independently of each other, or in silos if they want to achieve success for their organization. The primary concern for these officers should be every aspect of what is happening internally in the organization as well as the external environment; especially in the aspect of organizational effectiveness and efficiency.

\section{METHODOLOGY}

A mixed methods research design (Creswell, 2014) was used in this study. Creswell (2003) "defines mixed methods research by incorporating the definition that focuses on collecting and analyzing both quantitative and qualitative data in a single study" (p. 210). A sequential exploratory design involving qualitative (Eriksson and Kovalainen, 2008; Nardi, 2003) and quantitative (Elsbach and Bechky, 2009) methods was utilized in the collection and analysis of the data collected from a purposeful sample of $\mathrm{N}=399$ at fifty-seven SDA Local conference throughout North America (Bermuda, Canada and USA). The primary focus of this paper is quantitative pertaining to the study topic. ANOVAs, Likert Scale and Student-Newman-Keuls 
Post-Hoc Test were the primary statistical analysis used for each of the survey questions pertaining to the treasurer's relationship to the president.

\section{Research Question 1b}

\section{RESULTS}

Is there congruence between the perceptions of the presidents, treasurers and executive board members as they relate to the way the roles, responsibilities and relationships of the treasurers have changed?

The results summary of question $1 \mathrm{~b}$ pertaining to the treasurer's relationship with the president is presented with the means for the individual groups (presidents, treasurers, and board members). It should be noted that the Likert Scale used ranged from 1 (strongly disagree) through 5 (strongly agree). The higher the mean score, the more respondents agree with the survey questions.

\section{Individual Group Means for the Treasurer's Relationship to the President}

\begin{tabular}{l}
\hline Questions of Treasurer's Relationship to Presidents Presidents \\
\begin{tabular}{|l|l|l|l|l|}
\hline 21 & $\begin{array}{l}\text { Treasurers Board Members } \\
\text { present, future. }\end{array}$ & 3.62 & 3.68 \\
\hline 22 & Relationship is more a partnership and team. & 4.34 & 4.08 & 4.18 \\
\hline 23 & $\begin{array}{l}\text { Treasurer to support president regardless of } \\
\text { outcomes. }\end{array}$ & 1.97 & 2.38 & 2.02 \\
\hline 24 & $\begin{array}{l}\text { Time spent together enhances working } \\
\text { relationship. }\end{array}$ & 4.31 & 4.03 & 3.74 \\
\hline 25 & Communication is essential in building trust. & 4.74 & 4.69 & 4.62 \\
\hline 26 & Conflicts and disagreements are expected. & 3.34 & 3.34 & 3.36 \\
\hline 27 & Unified front in public is expected. & 4.06 & 4.18 & 3.87 \\
\hline 28 & $\begin{array}{l}\text { Treasurer should relocate if unable to work with } \\
\text { president. }\end{array}$ & 2.97 & 2.97 & 2.75 \\
\hline 29 & $\begin{array}{l}\text { A treasurer acting independently in decisions is } \\
\text { divisive. }\end{array}$ & 4.34 & 4.13 & 4.23 \\
\hline
\end{tabular}
\end{tabular}

IMPLICATIONS

In summary, the three groups (presidents, treasurers and board members) tended to be congruent regarding the treasurer's relationship to the present. The one question (\#24) where a significant difference between the groups of presidents and board members at the .05 level existed involved whether treasurers and presidents spending time together enhance their working relationship.

The total group's response indicates that it is essential for treasurers and presidents to spend time together, trust each other, and support each other to establish and maintain an effective working relationship.

\section{CONCLUSIONS}

Effective and viable CEOs and CFOs relationships significantly impact the organization's human resources and its operational climate and culture. Therefore, it's essentially critical that these relationships be maximized in the most positive and productive manner for the well-being of the conference and its subsidiaries and stakeholders. This leadership objective between the CEO and CFO would also promote an environment of effectiveness and efficiency in the overall organizational performance in a sustainable manner that would be very meaningful to all the 
conference stakeholders, and of greater importance in reflecting the church mission and modeling as the Body of Christ.

\section{References}

Adventist World - NAD (2013, June). Treasurer says north american tithe up 1 percent, 4.4 percent in other regions. p. 5.

Aquillio, M. (2016, February). Sarbanes-Oxley and the fishing expedition. ASBBS Proceedings. 23.1: 31-40. San Diego: San Diego American Society of Business and Behavioral Sciences.

Baker, C. (2016). CEOs adapt to a brave new world. Credit Control. 37.1/2:6-7.

Buckingham, M. and Coffman, C. (1999). First break all the rules: What the world's greatest managers do differently. New York: Simon \& Schuster.

Butcher, L. (2011, July). Building a great cfo. Charter. 82.6:48.

Caruso, J. (2015, Spring). Business \& industry. Pennsylvania CPA Journal. 86.1:10-11.

Creswell, J. (2003). Research design: Qualitative, quantitative, and mixed methods approaches (2nd ed.). Thousand Oaks, CA: Sage. p. 210.

Creswell, J. (2014). Research design: Qualitative, quantitative, and mixed methods approaches (4th ed.). Thousand Oaks, CA: Sage.

Elsbach, K.D. and Bechky, B.A. (2009). Qualitative Organizational Research (Vol. 2). Charlotte, NC. Information Age Publishing, Inc.

Eriksson P. and Kovalainen, A. (2008). Qualitative Methods in Business Research. Thousand Oaks, CA: Sage.

Franklin, M. (2016, July). Sarbanes-Oxley section 404: A historical analysis. Journal of Accounting and Finance. 16.4: 56-59.

Glamuzina, M. (2015, May). Levels of leadership development and top management's effectiveness: Is there a clear-cut relationship?*. Management: Journal of Contemporary Management Issues, suppl. The Life and Work of Professor Emeritus Marin, Split. 20:89.

Grove, C. (2016, February). Growing investor confidence. Accountancy SA. 38-39.

Horne, J.R. (2016). The nine critical questions managers should ask - A proposal for evaluating organizational efficiency. Journal of Strategic Innovation and Sustainability; West Palm Beach. 11.1:20-32.

Joseph, S.M. (2015, March). Board independence, corporate governance, and fraud: A review of the empirical research and direction for the future. Oil, Gas \& Quarterly. 63.3:433.

Kerns, C.D. (2015, December). Results management: A core leadership dimension. Journal of Leadership, Accountancy and Ethics; Lighthouse Point. 12.5:9-23.

Krishnan, G., Ramam, K.K., Yang, K., and Yu, W (2011, September). CFO/CEO - board social ties, Sarbanes-oaley, and earning management. Accounting Horizons. 25.3:537-557.

Lin (Jeffrey Frost), Y. and Orvis, B. (2016). Principles of management efficiency and organizational inefficiency. Kybernetes; London. 45.8: 1308-1322.

Malbasic, I. Marimon, F and Mas-Machuca, M. (2016). Is it worth having focused values? Management Decision; London. 54.10:2370-2392.

Moulton, D. (2016, August). Finance and it seen as stronger when sharing. Bottom Line. 32.9: 9, 19.

M2 Presswire [Coventry] (2012, September 4). The essential cfo: A corporate finance playbook. Coventry.

Nardi, P.M. (2003). Doing Survey Research: A Guide to Quantitative Methods. Boston, MA. Allyn and Bacon.

North American Division Working Policy (2015-2016). North American Division of the General Conference; Silver Springs, MD.

Ode, F. (2016, May/June). Who's leading your company? Look for the chief problem officer. Construction

Accounting \& Taxation. 26.3:6-10. 
Rangriz, H. and Soltanieh, F. (2015). Exploring the effects of organisational capabilities and managerial competencies on the organisational effectiveness. Journal of Strategic Human Resource Management; New Delhi. $4.2: \mathrm{n} / \mathrm{a}$.

Salhieh, L. and Abu-Doieh, J. (2015). The relationship between total quality management practices and their effects on bank's technical efficiency. International Journal of Commerce and Management; Bingley. 25.2:173-182.

Schiff, J., and Schiff, A. (2016, April). Get in gear! Strategic Finance. 97.10:24-31.

Seventh-day Adventist Accounting Manual, (2011 Edition/January). General Conference of Seventh-day Adventists. Silver Spring, Maryland. p. 4 -7.

Srivalli, P., Kota, N M K. (2016). Journal of Organization and Human Behaviour; New Delhi. 5.1:n/a.

Taylor, C. M., Cornelius, C.J. and Colvin, K. (2014). Visionary leadership and its relationship to organizational effectiveness. Leadership \& Organization Development Journal; Bradford. 35.6:583-566.

Vercic, D. and Zerfass, A. (2016). A comparative excellence framework for communication management. Journal of Communication Management; London. 20.4: 270-288.

Walter, J. (2014). Leadership styles and effectiveness in small, medium and large organizations. Capella University, ProQuest Dissertations Publishing, 3616067.

Whiteman, R. (2015, September). Necessary medicine. Public Finance. 9:17.

Yildiz, E. (2014). A study on the relationship between organizational culture and organizational performance and a model suggestion. International Journal of Research in Business and Social Science; Istanbul. 3.4: 52-67. 